\title{
Productivity and the presence of mycotoxins in oats, wheat, and triticale subjected to grazing
}

\section{Produtividade e presença de micotoxinas em grãos de aveia, trigo e triticale submetidos ao pastejo}

\author{
Loreno Egidio Taffarel ${ }^{1 *}$; Paulo Sérgio Rabello de Oliveira ${ }^{2}$; Jeferson Tiago Piano \\ Patricia Barcellos $\mathrm{Costa}^{2}$; Eduardo Eustáquio Mesquita²; Poliana Ferreira da \\ Costa $^{4}$; Deise Dalazen Castagnara ${ }^{5}$; Marcelina Bottoni Horn ${ }^{6}$; Elir de Oliveira ${ }^{7}$
}

\begin{abstract}
This study aimed to evaluate the effects of grazing on the agronomic characteristics, grain yield, and presence of the mycotoxins aflatoxins, fumonisins, and zearalenone in IPR 126 oat, BRS Tarumã wheat, and IPR 111 triticale. This study was performed from April 24, 2012 to November 11, 2013 at UNIOESTE's Experimental Farm in southern Brazil. The experimental design was a randomized block in a banded scheme, with four replications. The treatments in the A tracks were the three crops and the B tracks, the treatments: without grazing, one grazing event, or two grazing events. One grazing reduced the productivity of oat by $42.48 \%$ and triticale by $28.09 \%$ and increased wheat productivity by $24.89 \%$. Two grazings reduced oat productivity by $54.14 \%$, wheat by $40.96 \%$, and triticale by $54.69 \%$. Crops subjected to two grazings should be used for dry matter production for ground cover or partially used for silage when the plant is in the pasty or semi-hard grain stage, as grazing affects the agronomic characteristics and grain yield. The BRS Tarumã wheat, when used in crop-livestock integration systems, should be grazed only once due to increased productivity, while IPR 126 oat and IPR 111 triticale should not be grazed in crop-livestock integration systems for commercial production of grain. Oats from grazed plants should not be added to feeds of poultry in the early stage or pigs in the early and growth stages due to the higher levels of aflatoxins, fumonisins, and zearalenone. Grazing of winter crops increases the length of the crop cycle and grain formation will occur under climatic conditions favorable to the mycotoxins. Therefore, when grains are intended for human consumption, grazing is not recommended, as it increases the possibility of aflatoxins, fumonisins, and zearalenone at levels above the maximum tolerable levels permitted by law. These grains should be supplied to animals only after analysis of the mycotoxin levels present in the grains.
\end{abstract}

Key words: Aflatoxins. Crop-livestock integration. Dual-purpose cereals. Fumonisins. Grain yield. Zearalenone.

\footnotetext{
Médico Veterinário, Me. em Zootecnia, Dr. em Agronomia, Universidade Estadual do Oeste do Paraná, UNIOESTE, Marechal Cândido Rondon, PR, Brasil. E-mail: loreno.taffarel@gmail.com

2 Profs., Centro de Ciências Agrárias, UNIOESTE, Marechal Cândido Rondon, PR, Brasil. E-mail: rabello.oliveira@hotmail.com; patriciabarc@hotmail.com; e-mesquita@bol.com.br

3 Dr. em Agronomia, UNIOESTE, Marechal Cândido Rondon, PR, Brasil. E-mail: jefersontpiano@hotmail.com

$4 \mathrm{Dr}^{\mathrm{a}}$ em Ciência e Tecnologia Ambiental, Universidade Federal da Grande Dourados, UFGD, Dourados, MS, Brasil. E-mail: poliferreiradacosta@hotmail.com

5 Prof Adjunto, Universidade Federal do Pampa, UNIPAMPA, Uruguaiana, RS, Brasil. E-mail: deisecastagnara@yahooo.com.br

${ }^{6}$ Coordenadora do Laboratório de Bromatologia, Microbiologia e Micotoxinas da Nutrifarma, Taió, SC, Brasil. E-mail: marcelina@nutrifarma.ind.br

7 Pesquisador do Instituto Agronômico do Paraná, IAPAR, Cascavel, PR, Brasil. E-mail: drelir@gmail.com

Author for correspondence
} 


\section{Resumo}

Objetivou-se avaliar os efeitos dos pastejos nas características agronômicas, produtividade de grãos e presença das micotoxinas: aflatoxinas, fumonisinas e zearalenona em grãos de aveia IPR 126, trigo BRS Tarumã e triticale IPR 111. O trabalho foi desenvolvido no período de 24/04/2012 a 21/03/2014

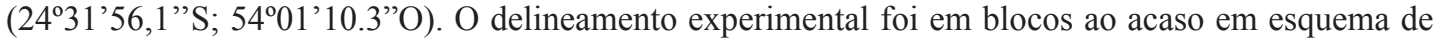
faixas, com quatro repetições. Os tratamentos nas faixas A foram as três culturas e nas faixas B os manejo:sem pastejo, um pastejo e dois pastejos. O manejo com apenas um pastejo reduziu a produtividade de grãos da aveia em $42,48 \%$ e do triticale em $28,09 \%$ e aumentou a produtividade do trigo em $24,89 \%$. O manejo com dois pastejos reduziu a produtividade da aveia em $54,14 \%$, do trigo em $40,96 \%$ e do triticale em $54,69 \%$. As culturas submetidas a dois pastejos devem ser diferidas para produção de matéria seca para cobertura do solo ou utilizar de forma parcial a planta no estágio de grãos pastosos ou semiduros para silagem, pois o pastejo prejudica as características agronômicas e produtividade. $\mathrm{O}$ trigo BRS Tarumã, quando utilizado em sistema de ILP deverá ser pastejado apenas uma vez com aumento de produtividade, enquanto a aveia IPR 126 e o triticale IPR 111 não devem ser pastejados em sistemas de integração lavoura pecuária para produção comercial de grãos. Grãos de aveia oriundos de plantas que foram submetidas a pastejo não devem ser adicionados em rações para aves na fase inicial e suínos na fase inicial e crescimento por possuírem maiores teores de aflatoxinas, fuminisinas e zearelenona. O pastejo das culturas de inverno aumenta o ciclo das culturas e a formação dos grãos ocorrerá em condições climáticas favoráveis à formação de micotoxinas. Por isso, quando o objetivo da produção de grãos de cereais de inverno é a alimentação humana, o pastejo não é recomendado, pois aumenta a possibilidade da presença de aflatoxinas, fumonisinas e zearalenona em limites máximos toleráveis acima do permitido pela legislação para a alimentação humana, e o fornecimento aos animais deve ocorrer após análises que indiquem os teores de micotoxinas presentes nos grãos.

Palavras-chave: Aflatoxinas. Cereais de duplo-propósito. Fumonisinas. Integração lavoura-pecuária. Produção de grãos. Zearalenona.

\section{Introduction}

In southern Brazil, crop-livestock integration (CLI) is an alternative to the rotation system, which uses winter grains in succession to summer crops and allows for a more efficient use of the soil. Crop rotation provides the property with higher diversity, lowering the economic risk of only producing grains, and improves the soil (SANTOS et al., 2013a). In western Paraná, where there is a rotation between soy in summer and corn in winter, crop rotation can be adapted to use CLI with dual-purpose winter grains.

For CLI with dual-purpose crops to be successful, there must be proper soil fertility, sowing at the appropriate time, and the right amount of rainfall. It is also important that there is no excessive trampling so that the soil porosity is not compromised, as this consequently impairs water infiltration and soil aeration, which contribute to the development of the summer crops' deep roots. In addition, the end of the grazing period must be before the elongation of the internodes of the plants, and must be timed so that the residual height of the crops assures a minimum of $2 \mathrm{t} \mathrm{ha}^{-1}$ of haystack on the stubble (BARTMEYER et al., 2011; CRUZ et al., 2010; HASTENPFLUG et al., 2011).

The regrowth of dual-purpose winter crops must be such that there is rapid formation of new leaves, to assure the production of photoassimilates necessary for grain formation. During leaf growth, there is a mobilization of carbohydrates and a progressive increase in the absorption of nitrogen, which reaches its peak during the reproductive stage and decreases during the grain-filling phase (HASTENPFLUG et al., 2011).

Cuts or grazing and fertilization levels can affect the production components (such as plant height, size of the cobs and panicles, plant density, the mass of one thousand grains (Thousand Grain Weight (TGW)), and grains per cob) of the winter crops 
used in CLI systems. These production components are directly related to the yield and quality of the winter crop grains (HASTENPFLUG et al., 2011). Grazing must be continued, regardless of the system put into place, whether rotated or continuous, until the plants reach the recommended height for the species, so that there is high performance and high forage quality. At the same time, the increase in soil quality and the reduction of compaction due to trampling (BALBINOT JUNIOR et al., 2009) must be controlled in a way that preserves, recovers, or increases soil fertility (HENZ et al., 2016). This way, livestock grazing will be seen as an activity that facilitates diversification and a higher income per area, and reduces agricultural risks (BALBINOT JUNIOR et al., 2009), especially when the goal is dual-purpose: cattle grazing and harvest (AMBROSI et al., 2001).

On the other hand, cereal grains can be contaminated by mycotoxins in the field or in storage. Grazing of winter crops increases the length of the crop cycle, exposing them to cold and damp or warm and damp conditions, both of which are favorable environments for the development of fungi, leading to mycotoxin contamination (NIELSEN et al., 2011).

It is estimated that approximately $25 \%$ of the world's agricultural products are contaminated by mycotoxins (IAMANAKA et al., 2010). Five types of mycotoxins are considered of economic interest: aflatoxins, zearalenone, fumonisins, ochratoxin A, and trichothecenes (LINO et al., 2004).

Thus, the aim of this study was to evaluate the agronomic characteristics, crop productivity, and the presence of mycotoxins aflatoxins, fumonisins, and zearalenone in oat, wheat, and triticale grains that were used in a CLI system.

\section{Materials and Methods}

The project was conducted between April 24, 2012 and November 11, 2013 on UNIOESTE's
Experimental Farm (latitude 24³1'56.1"S; longitude $54^{\circ} 01^{\prime} 10.3^{\prime \prime} \mathrm{W}$; approximate altitude of 400 m a.s.1.), Marechal Cândido Rondon Campus (PR, Brazil), on Dystrophic Red Latosol (Oxisol) (SANTOS et al., 2013b).

The climate in this region, according to Köppen's classification, is Cfa, or subtropical humid mesothermal with dry winters, rain welldistributed throughout the year, and warm summers. The average temperatures of the coldest trimester (Mai, June and July) vary between 17 and $18^{\circ} \mathrm{C}$, in the warmest trimester (December, January and February) are between 28 and $29^{\circ} \mathrm{C}$, and the annual average temperature is between 22 and $23^{\circ} \mathrm{C}$. The normal total annual average rainfall for the region varies between 1600 and $1800 \mathrm{~mm}$, with the most humid trimester receiving between 400 and $500 \mathrm{~mm}$ (CAVIGLIONE et al., 2000).

The climate data regarding the experimental period (April 2012 to November 2013) were obtained from a climatological station that belongs to UNIOESTE/Marechal Cândido Rondon and is approximately $50 \mathrm{~m}$ from the experimental area (Figure 1).

The experimental area was being maintained under the direct sowing system and, due to its chemical characteristics (Table 1) in which its base saturation was below $50 \%$, liming by applying agricultural limestone was performed (Relative Power of Total Neutralization - PRNT 85\%) before sowing of winter crops (March 2012); and before the soy crop (October 2012), with the goal of elevating the base saturation to $70 \%$ (SFREDO, 2008a).

The experimental design was random stripplotted blocks with four replicates. The treatments consisted of three winter cereal crops [IPR 126 oat (Avena sativa), BRS Tarumã wheat (Triticum sativum L.), and IPR 111 triticale $(\times$ Triticosecale Wittmack) on three A tracks $(10 \times 18 \mathrm{~m})$, and the three $\mathrm{B}$ tracks $(5 \times 30 \mathrm{~m})$ were the grazing treatments: without grazing (WG), one grazing 
event $(1 \mathrm{G})$, or two grazing events $(2 \mathrm{G})$. The plots were formed by the combination of the $\mathrm{A}$ and $\mathrm{B}$ tracks $(5 \times 10 \mathrm{~m})$, and the dates of sowing, grazing, and harvest, as well as the height of the crops before and after grazing (AMBROSI et al., 2001; LOPES et al., 2009; BARTMEYER et al., 2011; SANTOS et al., 2013a) are described in Table 2.

Figure 1. Average, maximum, and minimum temperature and accumulated rainfall $(\mathrm{mm})$ in the period between April 2012 to November 2013. S: oat, wheat, and triticale sowing; 1G: $1^{\text {st }}$ grazing (one grazing); $2 \mathrm{G}$ : $2^{\text {nd }}$ grazing (two grazings); $\mathrm{H} 1$ : harvest of the triticale without grazing, with one grazing, and with two grazings; $\mathrm{H} 2$ : harvest of the oat and wheat without grazing, with one grazing, and with two grazings; H3: harvest of the triticale without grazing; H4: harvest of triticale with one and two grazings and harvest of wheat without grazing and with one grazing; H5: harvest of oat without grazing, with one grazing, and with two grazings, and harvest of wheat with two grazings.

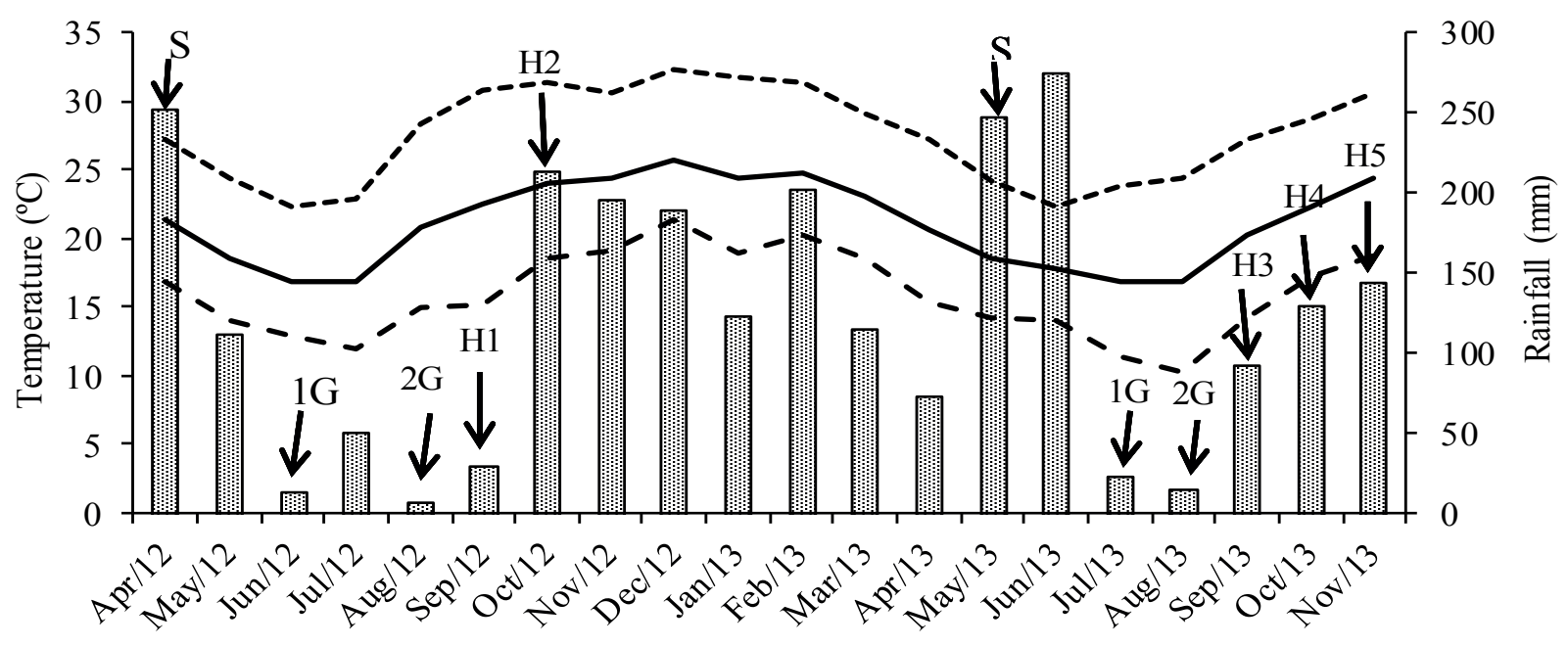

Months and year

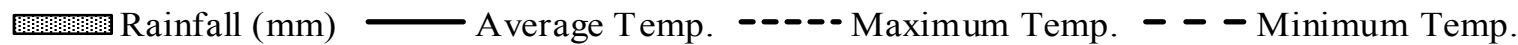

Table 1. Chemical and granulometric features of the soil, 0 to $30 \mathrm{~cm}$ deep, before planting of winter crops

\begin{tabular}{ccccccccccccccc}
\hline Depth & $\mathrm{P}$ & $\mathrm{MO}$ & $\mathrm{pH}$ & $\mathrm{H}+\mathrm{Al}$ & $\mathrm{Al}^{3+}$ & $\mathrm{K}^{+}$ & $\mathrm{Ca}^{2+}$ & & $\mathrm{SB}$ & $\mathrm{CEC}$ & $\mathrm{V}$ & Sand & Silt & Clay \\
\hline $\mathrm{cm}$ & $\mathrm{mg} \mathrm{dm}^{-3}$ & $\mathrm{~g} \mathrm{dm}^{-3}$ & $\mathrm{CaCl}_{2}$ & $--------------\mathrm{cmol}_{\mathrm{c}}$ & $\mathrm{dm}^{-3}-------------------$ & $\%$ & $--------\mathrm{g} \mathrm{kg}^{-1}--------$ \\
\hline $0-10$ & 24.49 & 32.64 & 4.55 & 9.4 & 0.46 & 0.53 & 4.56 & 1.54 & 6.63 & 16.02 & 41.7 & 681.0 & 266.5 & 52.52 \\
$10-20$ & 25.86 & 32.64 & 4.65 & 8.62 & 0.34 & 0.44 & 5.32 & 1.67 & 7.42 & 16.04 & 46.3 & 751.5 & 199.1 & 49.39 \\
$20-30$ & 12.11 & 32.47 & 4.77 & 7.47 & 0.19 & 0.25 & 5.49 & 1.75 & 7.49 & 14.95 & 50.1 & 706.5 & 238.9 & 54.57 \\
\hline
\end{tabular}

$\mathrm{P}$ and $\mathrm{K}-$ Extractor $\mathrm{MEHLICH}^{-1} ; \mathrm{Al}^{3+}, \mathrm{Ca}$, and $\mathrm{Mg}=\mathrm{KCl} 1 \mathrm{~mol} \mathrm{~L}^{-1} ; \mathrm{H}+\mathrm{Al}=\mathrm{pH} \mathrm{SMP}(7,5)$; $\mathrm{V}=$ base saturation

Source: Soil analysis of the experimental area. Environmental and Instrumental Chemistry Lab, UNIOESTE - Marechal Cândido Rondon Campus, 2012.

For sowing, $60 \mathrm{~kg} \mathrm{ha}^{-1}$ of IPR 126 oat and $90 \mathrm{~kg}$ ha $^{-1}$ of BRS Tarumã wheat were used in both 2012 and $2013 ; 40 \mathrm{~kg} \mathrm{ha}^{-1}$ of IPR 111 triticale was used in 2012 , and $60 \mathrm{~kg} \mathrm{ha}^{-1}$ in 2013. We used no-tillage system and the line spacing was $17 \mathrm{~cm}$.
Base fertilization for the crops was applied according to the TriticaleBrazilian Wheat and Triticale Research Commission (Comissão Brasileira de Pesquisa de Trigo e Triticale, 2011). Soil analysis showed that the rates of $\mathrm{P}(>20 \mathrm{mg}$ 
$\left.\mathrm{dm}^{-3}\right)$ and $\mathrm{K}\left(>0.3 \mathrm{cmol}_{\mathrm{c}} \mathrm{dm}^{-3}\right)$ were high, therefore, fertilization consisted of $100 \mathrm{~kg} \mathrm{ha}^{-1}$ NPK in an 8-20-20 formulation (SFREDO, 2008b). Coverage fertilization consisted of $120 \mathrm{~kg} \mathrm{ha}^{-1} \mathrm{~N}$ in the form of urea, which was applied in two steps in the WG and $1 \mathrm{G}$ plots, and in three steps in the $2 \mathrm{G}$ plots. The first treatment was at the time of tillering, 30 days after sowing, and the others were just after the grazing (Table 2).
The first grazing in 2012 took place 63 days after sowing (DAS) (June 26-29, 2012) and in 2013, 59 DAS (July 8-10, 2013). The second grazing took place 37 days after the first grazing in both 2012 and 2013 (August 2-4, 2012 and August 14-15, 2013). Ten Holstein cows with an average weight of $663 \mathrm{~kg}$ and average individual milk production of 25 liters daily were used for each grazing. After the grazings, the plots were managed for grain production.

Table 2. Sowing dates, grazing dates, average forage height for the entrance and exit of dairy cows, and dates of harvest of oat, wheat, and triticale crops.

\begin{tabular}{lcc}
\hline \multirow{2}{*}{ Item } & \multicolumn{2}{c}{ Year } \\
\cline { 2 - 3 } & 2012 & April 24, 2012 \\
\hline Sowing dates & May 10, 2013 \\
${\text { Dates of } 1^{\text {st }} \text { grazing }}_{\text {Dates of } 2^{\text {nd }} \text { grazing }}$ & June 26 293 DAS*) & July 8-10 (59 DAS) \\
Forage height (animals' entry) & August 2-4 (100 DAS) & August 14-15 (96 DAS) \\
Residual forage height (animals' exit) & $30 \mathrm{~cm}$ & $30 \mathrm{~cm}$ \\
Triticale harvest date - without grazing & $15 \mathrm{~cm}$ & $15 \mathrm{~cm}$ \\
Triticale harvest date - one grazing & September 15, 2012 & September 26, 2012 \\
Triticale harvest date - two grazings & September 15, 2012 & October 10, 2013 \\
Wheat harvest date - without grazing & September 15, 2012 & October 23, 2013 \\
Wheat harvest date - one grazing & October 18, 2012 & October 07, 2013 \\
Wheat harvest date - two grazings & October 18, 2012 & October 07, 2013 \\
Oat harvest date - without grazing & October 25, 2012 & November 11, 2013 \\
Oat harvest date - one grazing & October 18, 2012 & November 01, 2013 \\
Oat harvest date - two grazings & October 25, 2012 & October 07, 2013 \\
Harvest method & October 31, 2012 & October 07, 2013 \\
\hline
\end{tabular}

*DAS: days after sowing.

Agronomic characteristics and crop productivity

Before harvesting the crops, we measured the number of tillers per unit area, using a metallic board with a known area $\left(0.25 \mathrm{~m}^{2}\right)$. This count was repeated twice in each plot then converted to number per hectare. On ten plants, we measured the height of the plants and panicle size (spicula), obtained with the aid of a ruler scaled in millimeters, and the number of grains per cob. To evaluate the crop, we harvest $10 \mathrm{~m}^{2}$ from each plot (MEINERZ et al., 2012). It was necessary to stagger the harvests because the species that we worked with have different cycles. The IPR 126 oat and BRS Tarumã wheat have long cycles, and the IPR 111 triticale has a medium-length cycle (SILVA et al., 2006) (Table 2). After harvest, we measured TGW (BRASIL, 2009), and calculate total crop productivity.

The data were subjected to the Shapiro-Wilk test to verify normality, and those that did not have a normal distribution (grains per cob in 2012; grain 
productivity in the winter crops in both 2012 and 2013) were log-transformed. We analyzed the data with SISVAR software (FERREIRA, 2011), and the averages of the three treatments (without grazing, one grazing, and two grazings) for each crop were compared using the Tukey's test at the $5 \%$ probability level.

\section{Presence of Mycotoxins}

Grain samples were analyzed for the presence of aflatoxins, fumonisins, and zearalenone with an ELISA (enzyme linked immunosorbent assay) test from Neogen (Lansing, MI, USA) (SILVA, 2010) at the Nutrifarma Lab Analysis' Nutrilab Lab in Taió (SC, Brazil). Because the data did not meet the standards for parametric methods (GOMES, 1990), they were subjected to the Friedman test at the 5\% probability level.

\section{Results and Discussion}

A summary of the analyses of variance for plant height, plant density, cob and panicle sizes, TGW, grains per cob, and productivity of the IPR 126 oat, BRS Tarumã wheat, and IPR 111 triticale grown under the experimental CLI system in 2012 and 2013 is shown in Table 3.

Table 3. Middle square of plant height, plant density, cob and panicle sizes, Thousand Grain Weight, and number of grains per cob of IPR 126 oat, BRS Tarumã wheat, and IPR 111 triticale productivity in the years 2012 and 2013.

\begin{tabular}{lc}
\hline Variable & Interaction Crop $\times$ Treatment \\
\hline Pre-harvest plant height 2012 & $564.373683^{* *}$ \\
Pre-harvest plant height 2013 & $246.463186^{*}$ \\
Plant density $\left(\mathrm{m}^{-2}\right) 2012$ & $14923.419719^{*}$ \\
Plant density $\left(\mathrm{m}^{-2}\right) 2013$ & $6774.077649^{\mathrm{ns}}$ \\
Cob (panicle) size 2012 & $31.498915^{* *}$ \\
Cob (panicle) size 2013 & $0.829028^{\mathrm{ns}}$ \\
Grains per cob (panicle) 2012 & $0.015959^{*}$ \\
Grains per cob (panicle) 2013 & $26.176767^{*}$ \\
Thousand Grain Weight $(\mathrm{g}) 2012$ & $34.023212^{* *}$ \\
Thousand Grain Weight $(\mathrm{g}) 2013$ & $57.688999^{* *}$ \\
Grain productivity $\left(\mathrm{kg} \mathrm{ha}^{-1}\right) 2012$ & $2.878^{\mathrm{ns}}$ \\
Grain productivity $\left(\mathrm{kg} \mathrm{ha}^{-1}\right) 2013$ & $15.935^{* *}$ \\
\hline
\end{tabular}

ns: not significant; *significant at $5 \%$ according to an $\mathrm{F}$ test; ** significant at $1 \%$ according to an $\mathrm{F}$ test.

\section{Agronomic characteristics}

Plant height of oat was greatest in WG and of wheat and triticale in WG and 1G in 2012 (Table 4). In 2013, plant height of oat and triticale was greatest in WG and of wheat in WG and $1 \mathrm{G}$ (Table 4). There was a lodging of the oat crop, especially in WG, which can be explained by the greater height of the plants. Height of the BRS Tarumã wheat in both years was less than the $64.66 \mathrm{~cm}$ reported by
Menegol et al. (2012).

In 2012, oat plant density was largest in WG and $1 \mathrm{G}$, but there were no differences in wheat or triticale plant density based on grazing treatment. In 2013, there were no differences among WG, $1 \mathrm{G}$, and $2 \mathrm{G}$ in any of the three crops. The IPR 126 oat and the BRS Tarumã wheat, both of which are longcycle crops well-suited for grazing, reacted better to grazing than IPR 111 triticale, as reflected in their 
increased total plant density (Table 4), and tillering (NERES et al., 2012).

Final plant density was altered slightly due to the type of soil treatment with earlier crops, although it can be lower in wheat or soy monoculture systems when compared to systems with one or two years without wheat in the winter (SANTOS et al., 2012). However, in CLI systems, increasing the grazing period causes a decrease in the number of plants per square meter, although it increases the number of tillers per plant. For this reason, the number of cobs per area tends to be similar between treatments with or without grazing. However, cobs produced by these additional tillers are less-developed and smaller in size than the cobs produced by the main tillers; therefore, there is lower total grain productivity with grazing treatments (BARTMEYER et al., 2011), as seen in the treatments with two grazings (Table 5).

The largest oat panicles occurred with the WG treatments, but in wheat and triticale there were no differences in the sizes of the cobs among treatments in 2012. In 2013, there were no differences ( $p>$ 0.05 ) between treatments for panicle or cob size, although the cobs that came from WG plants were $6.32 \%, 43.90 \%$, and $29.49 \%$ larger than those from $2 \mathrm{G}$ oat, wheat, and triticale, respectively (Table 5). However, the treatments resulted in differences $(\mathrm{p}<$ 0.05 ) in number of grains per cob and productivity (Tables 5 and 6).

Table 4. Height and density of the plants before harvesting the IPR 126 oat, BRS Tarumã wheat, and IPR 111 triticale crops subjected to treatments with and without grazing in the years 2012 and 2013.

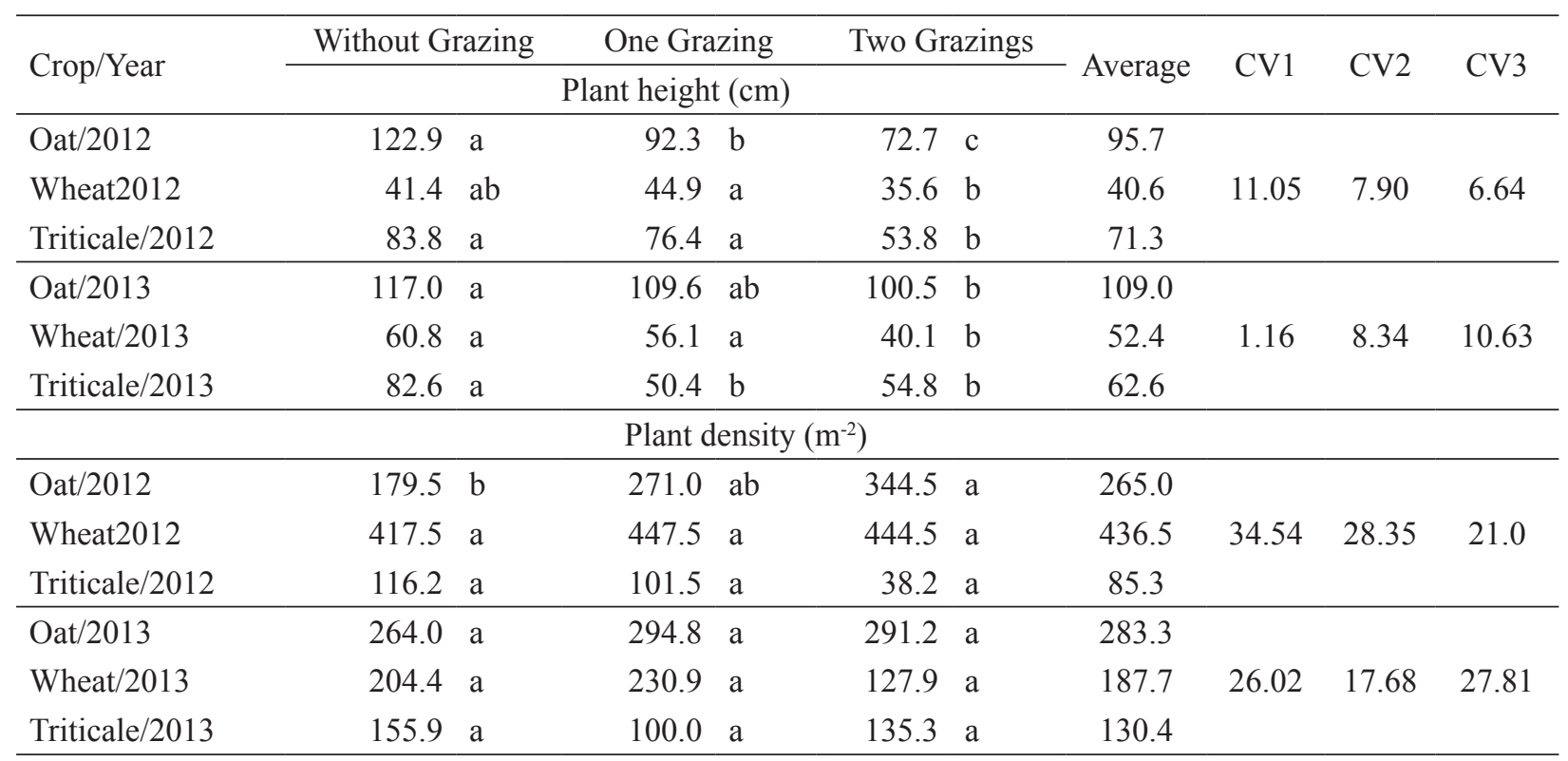

Averages followed by the same lowercase letter within a row did not differ according to the Tukey test at a $5 \%$ level of probability. 
Table 5. Size and number of grains per panicle or cob before harvesting the IPR 126 oat, BRS Tarumã wheat, and IPR 111 triticale crops subjected to treatments with or without grazing in the years 2013 and 2013.

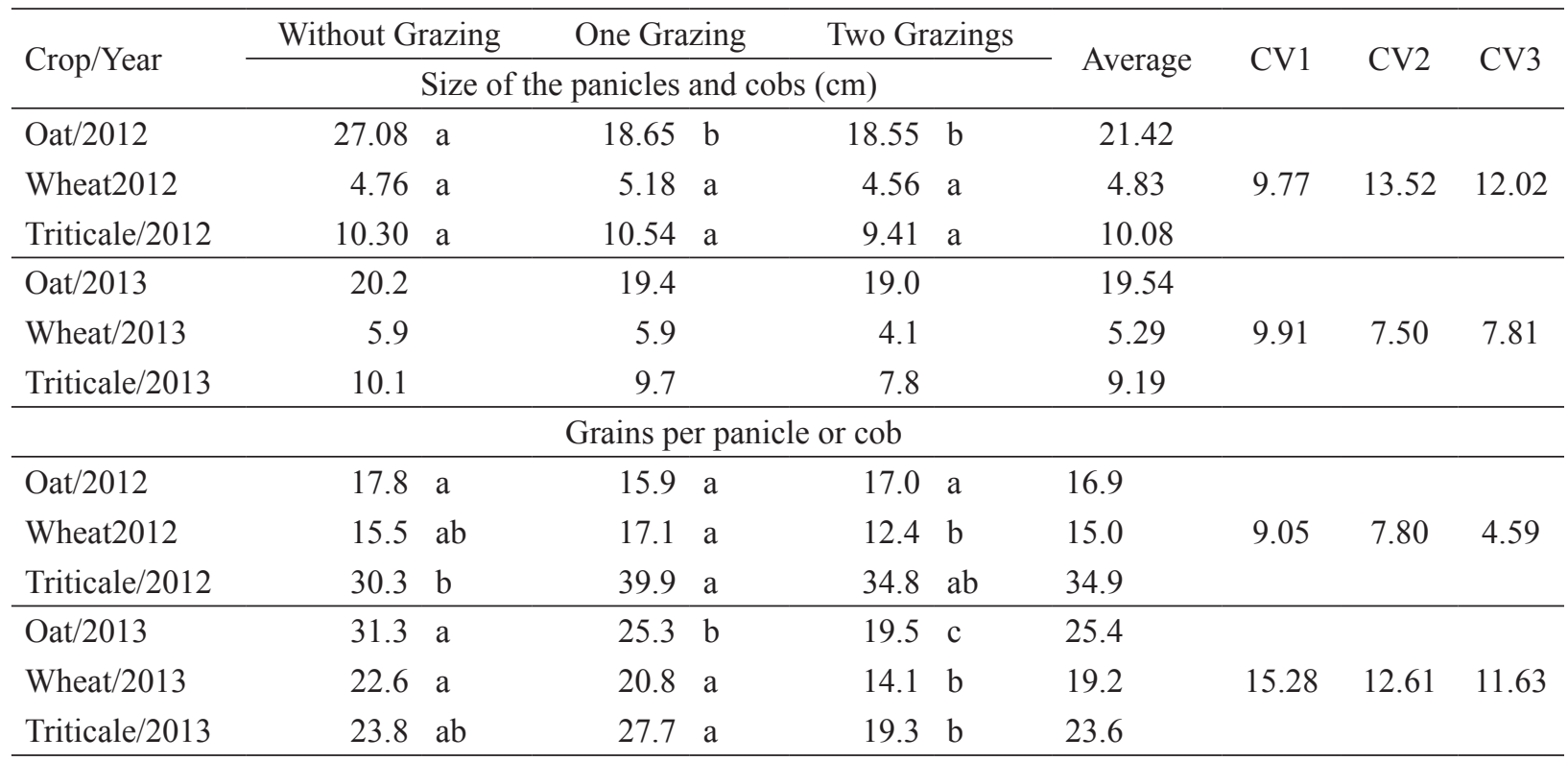

Averages followed by the same lowercase letter within a row did not differ according to the Tukey test at a $5 \%$ level of probability.

\section{Crop productivity}

There were no differences on the number of grains per panicle in oat in 2012 among the WG, 1G, and $2 \mathrm{G}$ treatments (Table 5). However, in wheat, the largest number of grains per cob occurred with the $1 \mathrm{G}$ treatment, although it was not statistically significantly different from other treatments. For the triticale, the largest number of grains per cob also occurred with the $1 \mathrm{G}$ treatment in both years, but in 2012 , there was no difference between this treatment and $2 \mathrm{G}$, nor was there a difference between $1 \mathrm{G}$ and WG in 2013.

In 2013, the largest number of grains occurred in the WG oat, and the $1 \mathrm{G}$ treatments had more grains than did the $2 \mathrm{G}$. For wheat and triticale, the $\mathrm{WG}$ and $1 \mathrm{G}$ treatments generally resulted in more grains, but the number of grains in triticale's WG treatment did not differ from that of its $2 \mathrm{G}$ treatment.

In 2013, there was $295.84 \%$ more rainfall during May, June, July, and August than in 2012 (654.4 $\mathrm{mm}$ vs. $221.2 \mathrm{~mm}$ ), which affected the number of grains per panicle or cob, especially in oat and wheat
(Table 5). Wheat needs approximately $322 \mathrm{~mm}$ of rain to complete its growth, which can vary from 450 to $600 \mathrm{~mm}$ in height (SANTOS et al., 2012). According to Castro et al. (2012), oat needs from $600 \mathrm{~mm}$ to $800 \mathrm{~mm}$ of rain for the winter and spring crop, with a higher need during blooming and the first stage of grain formation.

Low rainfall in 2012 might have led to higher volatilization of the $\mathrm{N}$ applied as fertilizer, especially after grazing, contributing to lower absorption of $\mathrm{N}$ by the roots. Since $\mathrm{N}$ is related to the differentiation of vegetative and reproductive tissues (REICHARDT et al., 2008), the lower water availability in 2012 might have interfered with this differentiation, especially in oat and wheat, which have a longer cycle than IPR 111 triticale. The maturation cycle of triticale lasts 127 days (SILVA et al., 2006), with cob formation after 70 days, while BRS Tarumã wheat has a late cycle, with cob formation after $110 \mathrm{DAS}$, and maturation after 162 days; IPR 126 oat also has a long 165-day cycle, blooming 108 days after its emergence. 
Table 6. Thousand Grains Weight (g), productivity $\left(\mathrm{kg} \mathrm{ha}^{-1}\right)$, and hectoliter weight of the grains in the IPT 126 oat, BRS Tarumã wheat, and IPR 111 triticale crops subjected to treatments with or without grazing in the years 2012 and 2013.

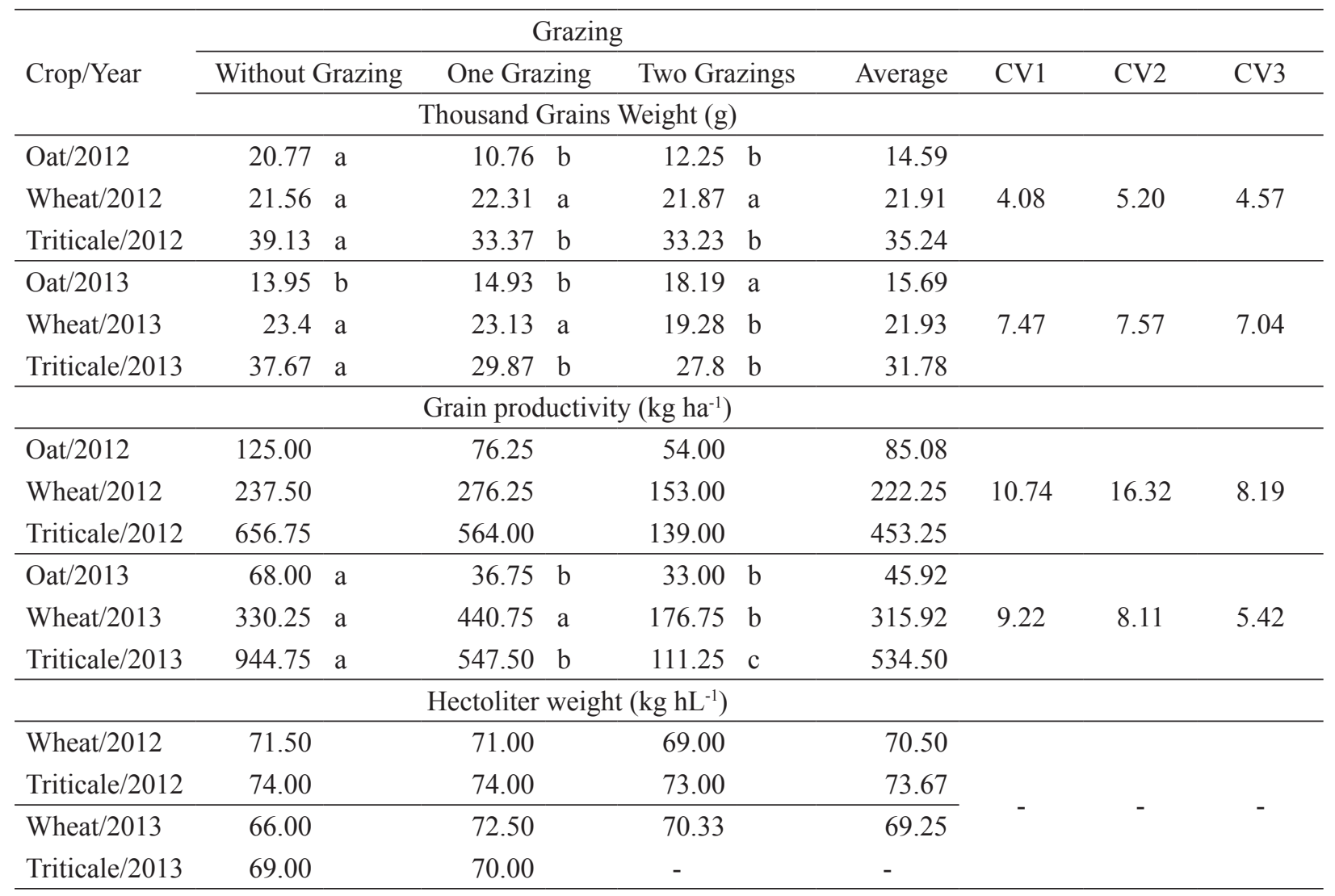

Averages followed by the same lowercase letter within a row did not differ according to the Tukey test at a 5\% level of probability.

TGW was highest for oat and triticale in WG, but there was no difference between the WG, $1 \mathrm{G}$, and $2 \mathrm{G}$ treatments for the BRS Tarumã wheat in 2012 (Table 6). In 2013, the highest TGW in oat was in the $2 \mathrm{G}$ plots, and there was no difference between the $1 \mathrm{G}$ and $\mathrm{WG}$ treatments. In wheat, the $\mathrm{WG}$ and $1 \mathrm{G}$ treatments resulted in a higher TGW and in triticale, WG had a higher TGW (Table 6). One explanation for the higher TGW of $2 \mathrm{G}$ oat in 2013 could be the higher level of rainfall and better distribution of rain in the period between May and October 2013 (783.6 $\mathrm{mm})$ when compared to the same period in 2012 (424.8 mm) (Figure 1).

The average TGW reported by Mariani et al. (2012) for BRS Tarumã wheat with $2 \mathrm{G}$ and a similar dose of $\mathrm{N}$ (total of $126 \mathrm{~kg} \mathrm{ha}^{-1}$ of $\mathrm{N}$ ) was $19.56 \mathrm{~g}$, similar to that in 2013 in this experiment with $2 \mathrm{G}$ and $120 \mathrm{~kg} \mathrm{ha}^{-1}$ of $\mathrm{N}$ (Table 6). TGW for the IPR 111 triticale can vary between 35 and $41 \mathrm{~g}$, with an average of $38 \mathrm{~g}$ (IAPAR, 2015b; SILVA et al., 2006). Grazing reduced the triticale TGW in both 2012 and 2013 (Table 6). Grazing reduces wheat and triticale productivity, and also reduces all other measurements of grain quality (BALKAN et al., 2011), while levels of $\mathrm{N}$ between 120 and $180 \mathrm{~kg}$ $\mathrm{ha}^{-1}$ increase the triticale TGW (MUT et al., 2005).

There were no differences $(\mathrm{p}>0.05)$ between the $\mathrm{WG}, 1 \mathrm{G}$, and $2 \mathrm{G}$ treatments in productivity of the three crops in 2012. The IPR 111 triticale and the BRS Tarumã wheat had the highest average grain productivity (453 $\mathrm{kg} \mathrm{ha}^{-1}$ and $222.2 \mathrm{~kg} \mathrm{ha}^{-1}$, respectively), while the IPR 126 oat had the lowest 
productivity $\left(85.0 \mathrm{~kg} \mathrm{ha}^{-1}\right)$ (Table 6$)$.

In 2013, the highest oat productivity occurred in the WG plots, and the BRS Tarumã wheat productivity was higher in the WG and $1 \mathrm{G}$ plots than the 2G. The IPR 111 triticale had its highest productivity in the WG plots, followed by the $1 \mathrm{G}$ plots, and its lowest productivity in the $2 \mathrm{G}$ plots (Table 6).
There was a reduction in the productivity of oat and triticale grains when treated with $1 \mathrm{G}$ and $2 \mathrm{G}$ in 2012 and 2013, respectively. For wheat, there was an increase with $1 \mathrm{G}$ and a reduction with $2 \mathrm{G}$ in both 2012 and 2013. The relative productivities of the three treatments in all three grains in both years can be seen in Figure 2.

Figure 2. Relative productivity (\%) of the IPR 126 oat, BRS Tarumã wheat, and IPR 111 triticale grains

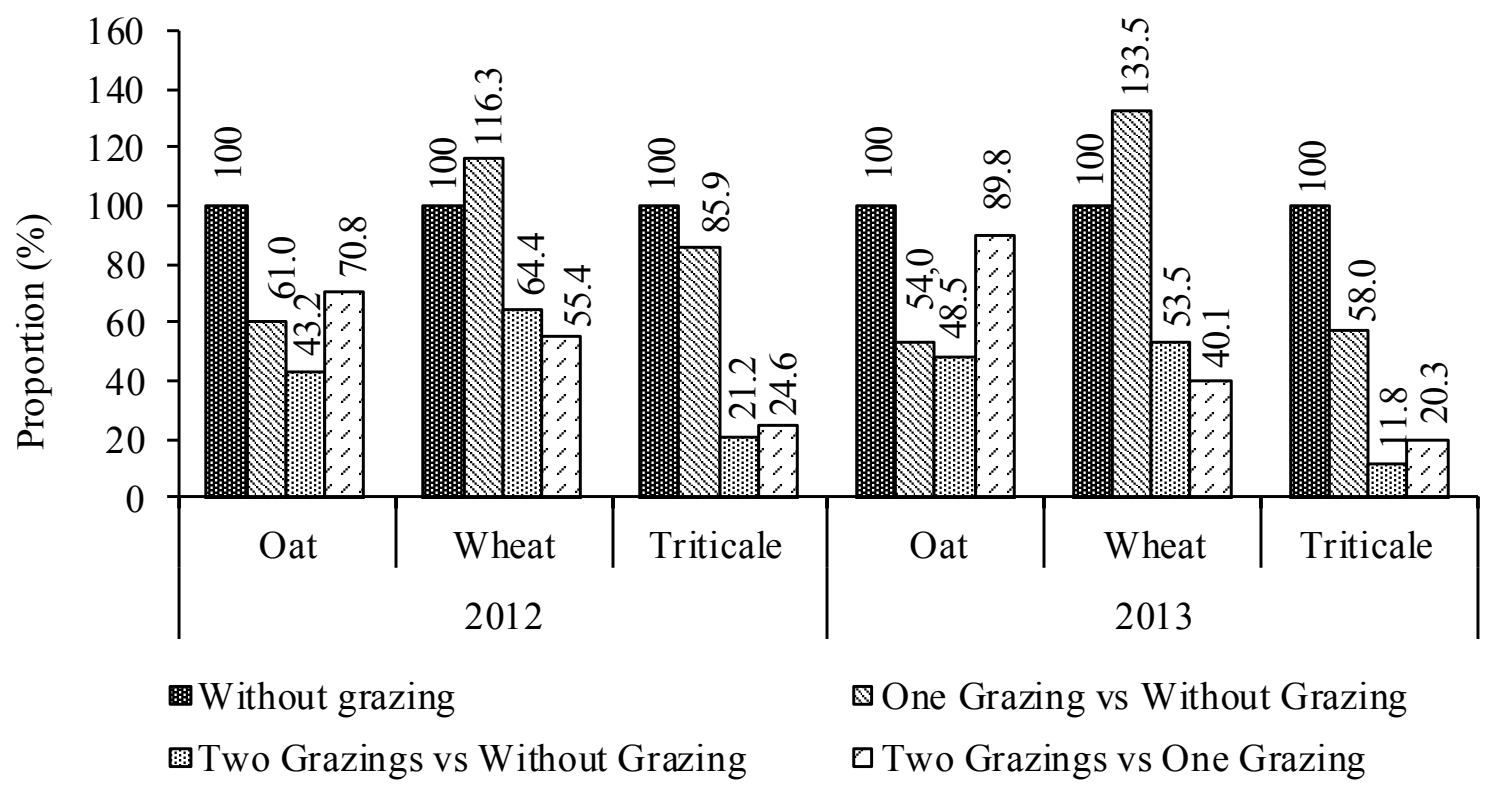

The average productivity reduction for oat was $42.48 \%$ with $1 \mathrm{G}$ and $54.14 \%$ with $2 \mathrm{G}$. For triticale, the average reduction was $28.09 \%$ with $1 \mathrm{G}$ and $83.53 \%$ with $2 \mathrm{G}$. For wheat with $1 \mathrm{G}$, there was an average productivity increase of $24.88 \%$ and for $2 \mathrm{G}$, there was a productivity decrease of $41.07 \%$. The tillering capacity of the grazed wheat contributed to these results, which is possible to verify with the plant density (Table 4), the greater size of the cobs, and the number of grains per cob (Table 5).

These grain productivities are below expectations for these crops. The IPR 126 oat grain productivity in western Paraná in 2003 to 2005 was $1311 \mathrm{~kg} \mathrm{ha}^{-1}$ with one cut, $2612 \mathrm{~kg} \mathrm{ha}^{-1}$ with two cuts, and 3147 $\mathrm{kg} \mathrm{ha}^{-1}$ with three cuts (IAPAR, 2017a). Triticale in 26 experiments, performed in triticale farm regions in Paraná during the years 1999 to 2003, had an average productivity of $3500 \mathrm{~kg} \mathrm{ha-1}$ (IAPAR, 2017b).

In Paraná, there are three different regions that produce wheat, and BRS Tarumã wheat is recommended only for region 1 (South-Central region and southeast Paraná, represented by Ponta Grossa, Guarapuava, and Palmas), while western Paraná, in the Marechal Cândido Rondon region, belongs to region 3 , suitable for producing wheat 
adapted warm weather, moderately dry climate, and low altitude (MONTECELLI et al., 2014).

Hastenpflug et al. (2011) reported BRS Tarumã wheat productivities of $1362.15 \mathrm{~kg} \mathrm{ha}^{-1}, 1175.25$ $\mathrm{kg} \mathrm{ha}^{-1}$, and $891.44 \mathrm{~kg} \mathrm{ha}^{-1}$ without cuts, with one cut, and with two cuts, respectively, in Pato Branco (PR, Brazil). These results were superior to the productivity in this experiment. Pitta et al. (2011) reported a decrease in BRS Tarumã wheat when it was grazed.

In Passo Fundo (RS, Brazil), a region suitable for production of BRS Tarumã wheat, productivity was $1178 \mathrm{~kg} \mathrm{ha}^{-1}$ after two grazings and fertilization with a total of $126 \mathrm{~kg} \mathrm{ha}^{-1} \mathrm{~N}\left(66 \mathrm{~kg} \mathrm{ha}^{-1} \mathrm{~N}\right.$ at sowing and more than $30 \mathrm{~kg} \mathrm{ha}^{-1} \mathrm{~N}$ after each grazing), and the productivity of black Agro Zebu oat under the same conditions was $885 \mathrm{~kg} \mathrm{ha}^{-1}$ (MARIANI et al., 2012).

Balkan et al. (2011) reported an average reduction in wheat and triticale yield of $8.43 \%$ with one grazing, $16.47 \%$ with two grazings, and $52.57 \%$ with three grazings. They also reported that the reduction in yield varied by year, species, cultivation, and grazing time.

Mut et al. (2005) reported an increase in triticale productivity when sowing 500 seeds per square meter with fertilization of $120 \mathrm{ha}^{-1} \mathrm{~N}$, including an increase of $79.43 \%$ to $99.64 \%$ when comparing the dose of $120 \mathrm{~kg} \mathrm{ha}^{-1} \mathrm{~N}$ with zero $\mathrm{N}$ in two crops. Since the current experiment used about 200 seeds per square meter, it is possible that seed density contributed to lower productivity of the IPR 111 triticale in this study.

Due to the low productivity, it is possible to use areas subjected to two grazings for silage production. The harvest for silage can be done when the crops are in the pasty or semi-hard grain stages. And the vegetative part of the plant must be used in a partial way (50\%) with the purpose to increase the amount of dry matter to cover the soil for sowing soy or corn in the summer in no tillage system.
The hectoliter weight in both years was between 69 and $74 \mathrm{~kg} \mathrm{hL}^{-1}$ (Table 6), within the expected range of variation for IPR 111 triticale, which is from 56 to $78 \mathrm{~kg} \mathrm{hL}^{-1}$ with an average of $67 \mathrm{~kg}$ $\mathrm{hL}^{-1}$ (SILVA et al., 2006). The hectoliter weight of triticale increases when it is fertilized with 120 to $180 \mathrm{~kg} \mathrm{ha}^{-1} \mathrm{~N}$ (MUT et al., 2005), and that may explain the results obtained here, as the total fertilizer used in the plots was $120 \mathrm{~kg} \mathrm{ha}^{-1} \mathrm{~N}$.

Hastenpflug et al. (2011) reported hectoliter weights of 74.53, 75.07, and $73.93 \mathrm{~kg} \mathrm{hL}^{-1}$ for BRS Tarumã wheat without cuts, with one cut, and with two cuts, respectively, which were superior to those from this experiment. An increase in maximum average temperature results in a reduction of the hectoliter weight at the beginning of grain filling, and increases TGW during the period that corresponds to the end of grain filling in the wheat crop (GUARIENTI et al., 2004). The lower hectoliter weight of the wheat grains here can be attributed to a temperature increase (Figure 1) that occurred after the second grazing in both years.

Santos et al. (2013a) concluded, after a 14-year study, that there were no differences in the hectoliter weight, TGW, number of cobs per plant, number of grains per plant, or grain mass per plant between wheat cultivated in a CLI system and no tillage system. This result differs from the results of this study for $2 \mathrm{G}$ of wheat, especially in the number of grains per cob (Table 5), TGW, and productivity (Table 6). On the other hand, a monoculture reduces TGW and hectoliter weight in wheat (GUARIENTI et al., 2005a). Guarienti et al. (2005b) also reported that precipitation at the beginning of the maturation stage reduces TGW and hectoliter weight, along with increasing the rate of mineral matter in the grains, especially in situations of excessive water on the ground and high humidity in the air. On September 30, 2013 and October 3, 2013 there was $31.0 \mathrm{~mm}$ and $42.0 \mathrm{~mm}$ of rainfall, respectively, which may explain the lower hectoliter weight in the absence of grazing (Figure 1). 


\section{Presence of Mycotoxins - Aflatoxins}

In 2012, the concentration of aflatoxins was highest in oat grains that were subjected to two grazings $\left(3.65 \mu \mathrm{g} \mathrm{kg}^{-1}\right)$. For wheat and triticale grains, there were no differences in the concentration of aflatoxins regardless of the treatment (Figure 3). The highest rate of aflatoxins in oat grains, in the $2 \mathrm{G}$ treatment, might be explained by the irregular maturation of the plants and the late harvest in a period of higher temperatures (Figure 1).

The amounts of aflatoxins in the oat, wheat, and triticale grains were within tolerated levels for an adult's diet, but above the maximum limit tolerated for children; the maximum tolerated limit (MTL) for aflatoxins in a child's diet is $1 \mu \mathrm{g} \mathrm{kg}^{-1}$ in cereal-based foods (BRASIL, 2011, 2013). The levels found here are above the maximums recommended for chicken and turkey in the initial phase and lactating cows (LAMIC, 2015).

Trombete et al. (2014) reported that $45.7 \%$ of samples of wheat for human consumption in Rio de Janeiro had an average aflatoxin concentration of $2.2 \mu \mathrm{g} \mathrm{kg}^{-1}$ and a maximum concentration of 6.2 $\mu \mathrm{g} \mathrm{kg}^{-1}$. In Europe, out of 2,183 samples processed between 2007 and 2012, 10.03\% were contaminated with aflatoxins at average concentrations of $2.21 \mu \mathrm{g}$ $\mathrm{kg}^{-1}$, and the highest amount was found in an oat bran that had $2.60 \mu \mathrm{g} \mathrm{kg}^{-1}$ (EFSA, 2013).

\section{Presence of Mycotoxins - Fumonisins}

The concentration of fumonisins did not differ according to treatment (Figure 3). The average concentration in the oat crop $\left(166.67 \mu \mathrm{g} \mathrm{kg}^{-1}\right)$ was $200.01 \%$ higher than the concentration found in the wheat crop $\left(83.33 \mu \mathrm{g} \mathrm{kg}^{-1}\right)$ and $399.98 \%$ higher than the concentration in the triticale grains $(41.67 \mu \mathrm{g} \mathrm{kg}$ $\left.{ }^{1}\right)$. In 2013, the amount of fumonisins in the oat was $50.0 \mu \mathrm{g} \mathrm{kg}^{-1}$ in WG, $100.0 \mu \mathrm{g} \mathrm{kg}^{-1}$ in $1 \mathrm{G}$, and 75.0 $\mu \mathrm{g} \mathrm{kg}^{-1}$ in $2 \mathrm{G}$. Fumonisins were not present in the wheat and triticale grains.

Fumonisins are associated with esophageal cancer in humans; they cause leukoencephalomalacia in horses, pulmonary edema in swine, and kidney toxicity in sheep (LINO et al., 2004). In birds, fumonisins lead to a reduction in performance and can cause severe immunosuppression (GERTNER et al., 2008). 
Figure 3. Concentrations ( $\mu \mathrm{g} \mathrm{kg}^{-1}$ ) of aflatoxins, fumonisins, and zearalenone in the grains of IPR 126 oat, BRS Tarumã wheat, and IPR 111 triticale crops subjected to treatments with or without grazing in 2012 and 2013.
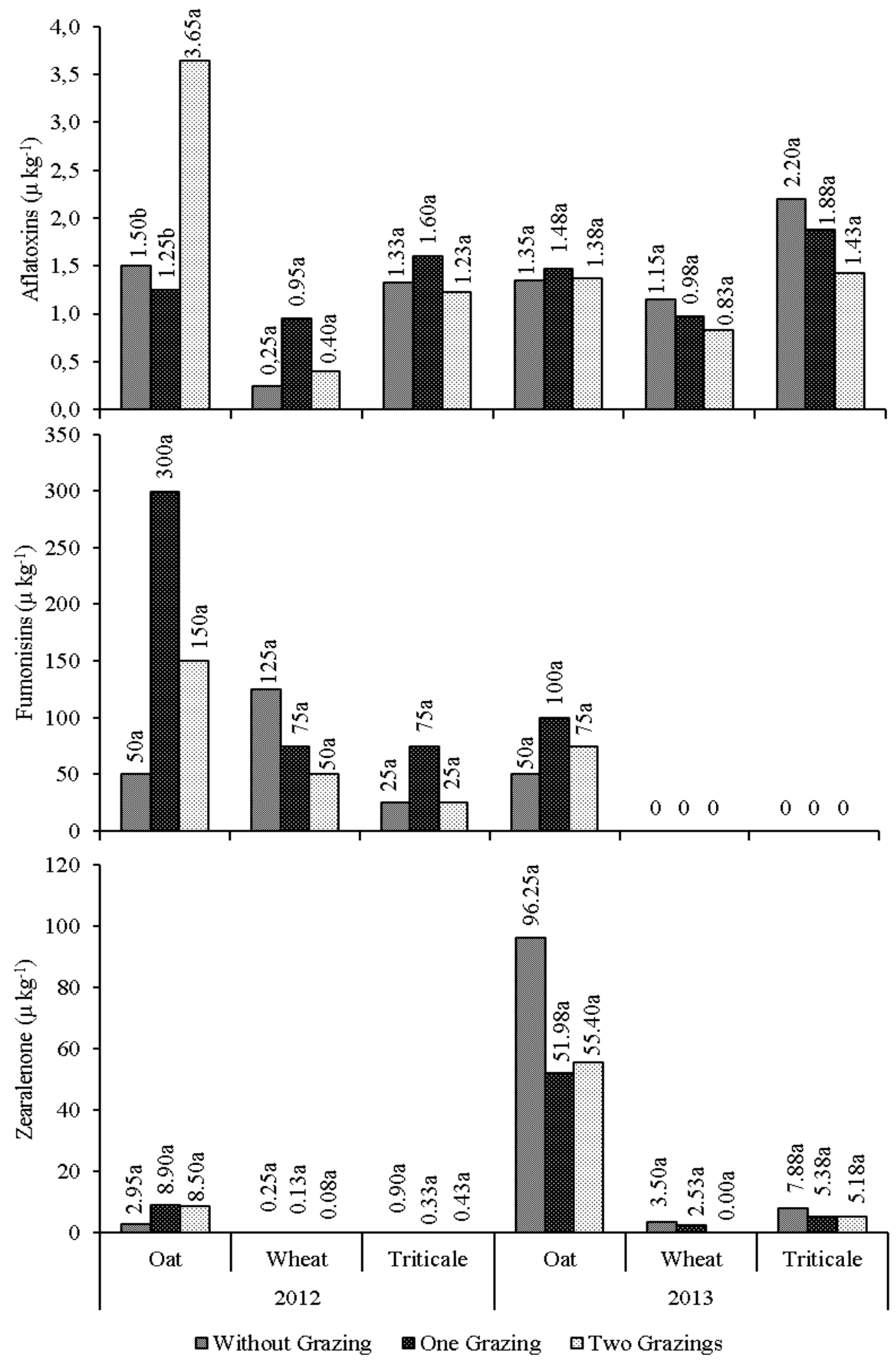

* Averages followed by the same lowercase letter within a row did not differ according to the Tukey test at a 5\% level of probability. 
Fumonisins are frequently associated with the pre-harvest conditions of the cereal, because the wheat, oat, and triticale are susceptible to contamination by the fungus Fusarium for twothirds of their life cycles. This fungus produces gibberellin in all climate situations (GERALDO et al., 2006). Gibberella is favored by the occurrence of rains, from cobs formation and during grain filling (TIBOLA et al., 2013). Because grazing elongates the crop cycle, it can increase the exposure of the plants to these climatic situations, and therefore increase the occurrence of disease and contamination by fumonisins.

In the Collegiate Board Resolutions (CDR) no. 7 and 59 of the Brazilian Health Regulatory Agency (ANVISA) (BRASIL, 2011), there is no limit placed on the presence of fumonisins in oat, wheat, or triticale grains. However, the MTL allows up to 200 $\mu \mathrm{g} \mathrm{kg}^{-1}$ in corn-based foods for breastfeeding women and young children. This limit was surpassed by the $1 \mathrm{G}$ oat grains in 2012 (Figure 3).

For animals, LAMIC's (2015) proposed MTL for fumonisins is $100 \mu \mathrm{g} \mathrm{kg}^{-1}$ for chicken and turkey in their initial phase and piglets in their initial and growing phases. Therefore, there is a restriction on the use of oat grains for these species and categories when the plants have been grazed. Therefore, according to Mallmann and Dilkin (2007), the $1 \mathrm{G}$ and $2 \mathrm{G}$ oat grains from 2012 would have been improper for consumption by any animal.

\section{Presence of Mycotoxins - Zearalenone}

The concentrations of zearalenone in the oat crop in 2012 were $2.95,8.90$, and $8.50 \mu \mathrm{g} \mathrm{kg}^{-1}$ in $\mathrm{WG}, 1 \mathrm{G}$, and $2 \mathrm{G}$, respectively. The amount of zearalenone in $1 G$ and $2 G$ were higher $(p<0.05)$ than in WG. For wheat, the concentration of zearalenone in $\mathrm{WG}$ was $0.25 \mu \mathrm{g} \mathrm{kg}^{-1}$, in $1 \mathrm{G}$ it was $0.125 \mu \mathrm{g} \mathrm{kg}^{-1}$, and in $2 \mathrm{G}$, $0.075 \mu \mathrm{g} \mathrm{kg}^{-1}$. For triticale, the concentrations were $0.90 \mu \mathrm{g} \mathrm{kg}^{-1}, 0.325 \mu \mathrm{g} \mathrm{kg}^{-1}$, and $0.425 \mu \mathrm{g} \mathrm{kg}^{-1}$ in $\mathrm{WG}, 1 \mathrm{G}$, and $2 \mathrm{G}$, respectively (Figure 3 ).
In 2013, there were no differences in the concentration of zearalenone due to treatment. Notably, there was a significant increase in zearalenone in the IPR 126 oat grains, with 96.25 , 51.98 , and $55.40 \mu \mathrm{g} \mathrm{kg}^{-1}$ in $\mathrm{WG}, 1 \mathrm{G}$, and $2 \mathrm{G}(+$ $3162.71 \%$, $+484 \%$ and $+551.76 \%$ in relation to 2012), respectively. Zearalenone also increased in wheat and triticale grains in 2013, compared to 2012, although the increase was not as significant. The results of this study are similar to those of Twaruzek et al. (2013) and Nordkvist and Häggblom (2014), who reported that fumonisins occurred with great frequency with zearalenone in wheat grains (STANKOVIC et al., 2012).

Zearalenone is similar to estrogen and causes hyperestrogenism in swine, affects the fertility of bovines, and interferes with secondary sexual development in calves. In humans, it has been implicated in changes during puberty (IAMANAKA et al., 2010).

These toxins also increase when crops are exposed to higher temperatures, relative humidity, and rain (FELS-KLERX et al., 2012), which suggests that, because grazing increases the length of the crop cycle, especially in IPR 126 oat, which has the longest cycle, it also favors the presence of the Fusarium mycotoxins.

Tibola et al. (2013) reported that in southern Brazil, zearalenone was found in $31 \%$ of the 396 wheat samples analyzed between 2009 and 2012, with an average of $317 \mu \mathrm{g} \mathrm{kg}^{-1}$. However, the range was 20 to $2960 \mu \mathrm{g} \mathrm{kg}^{-1}$. The MTL for zearalenone in cereal-based foods in a child's diet is $20 \mu \mathrm{g} \mathrm{kg}^{-1}$ (BRASIL, 2011). Therefore, the concentrations of zearalenone in wheat and triticale in this study were within the tolerable limits. However, in 2013 (Figure 3), the concentration of zearalenone in IPR 126 oat grains in all three treatments (WG, $1 \mathrm{G}$, and $2 \mathrm{G})$ were above the MTL for child nutrition. 


\section{Conclusions}

The primary effect of two grazings on the IPR 126 oat, BRS Tarumã wheat, and IPR 111 triticale crops was a reduction in yield due to negative effects on the agronomic characteristics such as height and number of grains per cob, making the commercial harvest unfeasible. BRS Tarumã wheat must be grazed only once when used in a CLI system, as this leads to a productivity increase. Grazing is not recommended for IPR 111 triticale due to its short cycle but is an alternative to anticipate sowing of summer crops at the beginning of the sowing period.

IPR 126 oat grains, regardless of whether the crop was grazed or not, had elevated levels of aflatoxins, fumonisins, and zearalenone. Therefore, they were not suitable for human consumption and should not be fed to chickens in the initial phase, swine in the initial and growth phases, or lactating cows.

Grazing of winter crops increases the length of the crop cycle, and the formation of grains occurs during climatic conditions that are favorable to mycotoxins. Therefore, when the goal of winter cereal grain production is human nutrition, grazing is not recommended, because it increases the probability of the presence of aflatoxins, fumonisins, and zearalenone at levels above the maximum tolerable limits allowed by law. Supplying these grains to animals must occur only after the analysis of mycotoxin concentrations.

\section{References}

AMBROSI, I.; SANTOS, H. P.; FONTANELI, R. S.; ZOLDAN, S. M. Lucratividade e risco de sistemas de produção de grãos combinados com pastagens de inverno. Pesquisa Agropecuária Brasileira, Brasília, v. 36, n. 10, p. 1213-1219, 2001.

BALBINOT JUNIOR, A. A.; MORAES, A.; VEIGA, M.; PELISSARI, A.; DIECKOW, J. Integração lavourapecuária: intensificação de uso de áreas agrícolas. Ciência Rural, Santa Maria, v. 39, n. 6, p. 1925-1933, 2009.

BALKAN, A.; ÖZDÜVEN, M. L.; NIZAM, I.; TEYKIN, E. E.; TUNA, M. The effect of grazing applied in the different phenological stages on yield and yield components of bread wheat and triticale. Journal of Tekirdag Agricultural Faculty, Tekirdag, v. 8, n. 1, p. 93100, 2011.

BARTMEYER, T. N.; DITTRICH, J. R.; SILVA, H. A.; MORAES, A.; PIAZZETTA, R. G.; GAZDA, T. L.; CARVALHO, P. C. F. Wheat de duplo propósito submetido a pastejo de bovino nos Campos Gerais do Paraná. Pesquisa Agropecuária Brasileira, Brasília, v. 46, n. 10, p. 1247-1253, 2011.

BRASIL. Ministério da Agricultura, Pecuária e Abastecimento. Regras para análise de sementes. Ministério da Agricultura, Pecuária e Abastecimento. Secretaria de Defesa Agropecuária. Brasília: Mapa/ACS, 2009. 399 p.

Resolução - RDC no 7, de 18 de fevereiro de 2011. Dispõe sobre limites máximos tolerados (LMT) para micotoxinas em alimentos. Diário Oficial [da] República Federativa do Brasil, Brasília, 9 mar. 2011. Seção 1, p. 66-67.

Resolução - RDC n ${ }^{\circ} 59$, de 26 de dezembro de 2013. Dispõe sobre a prorrogação dos prazos estabelecidos nos artigos 11 e 12 e respectivos anexos III e IV da Resolução da Diretoria Colegiada RDC n. 7, de 18 de fevereiro de 2011 que dispõe limites máximos tolerados (LMT) para micotoxinas em alimentos. Diário Oficial [da] República Federativa do Brasil, Brasília, 30 dez. 2013. Seção 1, p. 756.

CASTRO, G. S. A.; COSTA, C. H. M.; FERRARI NETO, J. Ecofisiologia da Oat branca. Scientia Agraria Paranaensis, Marechal Cândido Rondon, v. 11, n. 3, p. 1-15, 2012.

CAVIGLIONE, J. H.; KIIHL, L. R. B.; CARAMORI, P. H.; OLIVEIRA, D. Cartas climáticas do Paraná: versão 1.0. Londrina: Instituto Agronômico do Paraná, 2000. CD-ROM. Available at: <http:/www.iapar.br/modules/ conteudo/conteudo.php? conteudo $=677>$. Accessed at: 3 ago. 2017.

COMISSÃO BRASILEIRA DE PESQUISA DE TRIGO E TRITICALE. Informações técnicas para trigo e triticale - safra 2012. Dourados, MS: Embrapa Agropecuária Oeste, 2011. 204 p.

CRUZ, J. C.; PEREIRA FILHO, I. A.; ALVARENGA, R. C.; GONTIJO NETO, M. M.; VIANA, J. H. M.; OLIVEIRA, M. F.; MATRANGOLO, W. J. R. Cultivo do milho. 6. ed. Brasília: Embrapa Milho e Sorgo, 2010. (Sistema de Produção, 1). Available at: <http://www. cnpms.embrapa.br/publicacoes/milho $6 \quad$ ed/index. htm>. Accessed at: 3 dez. 2014.

EUROPEAN FOOD SAFETY AUTHORITY - EFSA. 
Aflatoxins (sum of B1, B2, G1, G2) in cereals and cereal-derived food products. Parma: EFSA, p. 1-11. (Supporting Publications, EN-406).

FELS-KLERX, H. J. Van Der; KLEMSDAL, S.; HIETANIEMI, V.; IOANNOU-KAKOURI, E.; ASSELT, E. D. Van. Mycotoxin contamination of cereal grain commodities in relation to climate in North West Europe. Food Additives Contaminants, Bethesda, v. 29, n. 10, p. 1581-1592, 2012.

FERREIRA, D. F. Sisvar: a computer statistical analysis system. Ciência e Agrotecnologia, Lavras, v. 35, n. 6, p. 1039-1042, 2011.

GERALDO, M. R. F.; TESSMANN, D. J.; KEMMELMEIER, C. Production of mycotoxins by Fusarium graminearum isolated from small cereals (wheat, triticale and barley) affected with scab disease in southern Brazil. Brazilian Journal of Microbiology, São Paulo, v. 37, n. 1, p. 58-63, 2006.

GERTNER, L. R. S.; SANTIN, E.; SAAD, M. B. Influência da fumonisina sobre a resposta imunológica de aves: revisão bibliográfica. Revista Acadêmica Ciência Animal, Curitiba, v. 6, n. 3, p. 401-411, 2008.

GOMES, F. P. Curso de estatística experimental. 13. ed. Piracicaba: Universidade de São Paulo, 1990. 466 p.

GUARIENTI, E. M.; CIACCO, C. F.; CUNHA, G. R.; DEL DUCA, L. J. A.; CAMARGO, C. M. O. Efeitos da precipitação pluvial, da umidade relativa do ar e de excesso e déficit hídrico do solo no peso do hectolitro, no peso de mil grãos e no rendimento de grãos de Wheat. Ciência e Tecnologia de Alimentos, Campinas, v. 25, n. 3, p. 412-418, 2005 b.

Influência das temperaturas mínima e máxima em características de qualidade industrial e em rendimento de grãos de Wheat. Ciência e Tecnologia de Alimentos, Campinas, v. 24, n. 4, p. 505-515, 2004.

GUARIENTI, E. M.; SANTOS, H. P.; LHAMBY, J. C. B. Efeito de sistemas de rotação de culturas sobre características de qualidade tecnológica de Wheat. Pesquisa Agropecuária Gaúcha, Porto Alegre, v. 11, n. 1-2, p. 31-37, 2005a.

HASTENPFLUG, M.; MARTIN, T. N.; BRAIDA, J. A.; BARBOSA, D. K.; ZIELINSKI, R. P.; REFATTI, R. Graind yield of dual-purpose wheat cultivars as affected by nitrogen and cuttings. Bragantia, Campinas, v. 70, n. 4, p. 819-824, 2011.

HENZ, E. L.; ALMEIDA, P. S. G.; VELHO, J. P.; NÖRNBERG, J. L.; SILVA, L. D. F.; BACKES, T. R.; GUERRA, G. L. Dual purpose wheat production with different levels of nitrogen topdressing. Semina: Ciências Agrárias, Londrina, v. 37, n. 2, p. 1091-1100, 2016.
IAMANAKA, B. T.; OLIVEIRA, I. S.; TANIWAKI, M. H. Micotoxinas em alimentos. Anais da Academia Pernambucana de Ciência Agronômica, Recife, v. 7, p. 138-161, 2010.

INSTITUTO AGRONÔMICO DO PARANÁ - IAPAR. Oat Branca IPR 126. Londrina: Iapar, 2017a. (folder). Available at: <http://www.iapar.br/arquivos/File/zip_ pdf/aveia-branca.pdf $>$. Accessed at: 9 ago. 2017.

Triticale IPR 111. Londrina: Iapar, 2017b. (folder). Available at: <http://www.iapar.br/arquivos/ File/folhetos/tricale/tricale111.html>. Accessed at: 8 ago. 2017.

LABORATÓRIO DE ANÁLISES MICOTOXICOLÓGICAS - LAMIC. Recomendações do LAMIC de limites máximos de micotoxinas $(\mu \mathrm{g} / \mathrm{kg})$ em alimentos de algumas espécies de animais domésticos. Santa Maria: Lamic, 2015. Available at: <http://www. lamic.ufsm.br/web/?q=legislacao_brasil $>$. Accessed at: 25 ago. 2015.

LINO, C. M.; SILVA, L. J. G.; PENA, A. S. Fumonisinas: presença em alimentos, implicações na saúde e aspectos legislativos. Revista Portuguesa de Ciências Veterinárias, Coimbra, v. 99, n. 552, p. 181-192, 2004.

LOPES, M. L. T.; CARVALHO, P. C. F.; ANGHINONI, I.; SANTOS, D. T.; AGUINAGA, A. A. Q.; FLORES, J. P. C.; MORAES, A. Sistema de integração lavourapecuária: efeito do manejo da altura em pastagem de Oat preta e azevém anual sobre o rendimento da cultura da soja. Ciência Rural, Santa Maria, v. 39, n. 5, p. 14991506, 2009.

MALLMANN, C. A.; DILKIN, P. Micotoxina $e$ micotoxicoses em suinos. Santa Maria: Do Autor, 2007. $240 \mathrm{p}$.

MARIANI, F.; FONTANELI, R. S.; VARGAS, L.; SANTOS, H. P.; FONTANELI, R. S. Wheat de duplo propósito e Oat preta após forrageiras perenes e culturas de verão em sistema de integração lavoura-pecuária. Ciência Rural, Santa Maria, v. 42, n. 10, p. 1752-1757, 2012.

MEINERZ, G. R.; OLIVO, C. J.; FONTANELI, R. S.; AGNOLIN, C. A.; HORST, T.; BEM, C. M. de. Produtividade cereais de inverno de duplo propósito na depressão central do Rio Grande do Sul. Revista Brasileira de Zootecnia, Viçosa, MG, v. 41, n. 4, p. 873882, 2012.

MENEGOL, D. R.; ZWIRTES, A. L.; BATTISTI, R.; BARONIO, C. A.; ROSA, G. M. Produtividade e qualidade da forragem e dos grãos produzidos por duas cultivares de trigo duplo propósito. Enciclopédia Biosfera, Goiânia, v. 8, n. 14, p. 787-797, 2012. 
MONTECELLI, A.; DENGLER, R. U.; LOMBARDI, J. Informações técnicas para trigo e triticale - safra 2014. In: REUNIÃO DA COMISSÃO BRASILEIRA DE PESQUISA DE TRIGO E TRITICALE, 7., 2014, Londrina: Fundação Meridional, 2014. 235 p.

MUT, Z.; SEZER, I.; GÜLÜMSER, A. Effect of different sowing rates and nitrogen levels on grain yield, yield components and some quality traits of triticale. Asian Journal of Plant Sciences, Deira, v. 4, n. 5, p. 533-539, 2005.

NERES, M. A.; CASTAGNARA, D. D.; OLIVEIRA, P. S. R.; OLIVEIRA, E.; JOBIM, C. C.; TRES, T. T.; MESQUITA, E. E. IPR 126 white oat forage potential under free growth, cutting and grazing at two management heights. Revista Brasileira de Zootecnia, Viçosa, MG, v. 41, n. 4, p. 889-897, 2012.

NIELSEN, L. K.; JENSEN, J. D.; JENSEN, J. E.; SPLIID, N. H.; THOMSEN, I. K.; JUSTESEN, A. F.; COLLINGE, D. B.; JØRGENSEN, L. N. Fusarium heab blight of cereal in Denmark: species and related mycotoxins. Phytopathology - Population Biology, Davis, v. 101, n. 8, p. 960-969, 2011.

NORDKVIST, E.; HÄGGBLOM, P. Fusarium mycotoxin contamination of cereals and bedding straw at Swedish pig farms. Animal Feed Science and Technology, Amsterdam, v. 198, p. 231-237, 2014.

PITTA, C. S. R.; SOARES, A. B.; ASSMANN, T. S.; ADAMI, P. F.; SARTOR, L. R.; MIGLIORINI, F.; SOLLENBERGER, L. E.; ASSMANN, A. L. Dualpurpose wheat grain and animal production under different grazing periods. Pesquisa Agropecuária Brasileira, Brasília, v. 46, n. 10, p. 1385-1391, 2011.

REICHARDT, J.; MAUAD, M.; WOLSCHIK, D. Adubação nitrogenada aplicada no início do perfilhamento da Oat preta. Agrarian, Dourados, v. 1, n. 2, p. 71-81, 2008.

SANTOS, H. G.; JACOMINE, P. K. T.; ANJOS, L. H. C.; OLIVEIRA, V. A.; LUMBRERAS, J. F.; COELHO, M. R.; ALMEIDA, J. A.; CUNHA, T. J. F.; OLIVEIRA, J. B. Sistema brasileiro de classificação de solos. 3. ed. revisada e ampliada. Brasília: EMBRAPA, 2013b. 353 p.

SANTOS, H. P.; FONTANELI, R. S.; CAIERÃO, E.; DREON, G.; LAMPERT, E. A. Sistemas de manejo e rotação de culturas no rendimento de grãos e nas características agronômicas de Wheat. Revista Brasileira de Ciências Agrárias, Recife, v. 7, n. 3, p. 478-484, 2012.
SANTOS, H. P.; FONTANELI, R. S.; CASTRO, R. L.; FONTANELI, R. S.; LAMPERT, E. A. Rendimento de grãos de trigo em sistemas de produção com integração lavoura-pecuária, sob plantio direto. Revista Brasileira de Ciências Agrárias, Recife, v. 8, n. 3, p. 408-415, 2013a.

SFREDO, G. J. Calagem e adubação da soja. Londrina: Embrapa Soja, 2008a. 12 p. (Circular técnica, 61). Available at: <http://ainfo.cnptia.embrapa.br/digital/ bitstream/CNPSO-2009-09/28580/1/circtec61.pdf $>$. Accessed at: 3 ago. 2017.

Soja no Brasil: calagem, adubação e nutrição mineral. Londrina: Embrapa Soja, 2008b. 147 p. (Documentos 305). Available at: <http://www.cnpso. embrapa.br/download/Doc305.pdf>. Accessed at: 23 ago. 2017.

SILVA, A. C.; RIEDE, L. A. C.; POLA, J. N.; SHIOGA, P. S. Cultivar release - IPR 111 - Triticale cultivar. Crop Breeding and Applied Biotechnology, Viçosa, v. 6, p. 250-252, 2006.

SILVA, L. C. Micotoxinas em grãos e derivados. Alegre: Universidade Federal do Espírito Santo, Departamento de Engenharia Rural, 2010. 10 p. (Boletim técnico).

STANKOVIC, S.; LEVIĆ, J.; IVANOVIĆ, D.; KRNJAJA, V.; STANKOVIĆ, G.; TANĆIĆ, S. Fumonisin B1 and its co-occurrence with others fusiotoxins in naturallycontaminated wheat grain. Food Control, Vurrey, v. 23, p. 384-388, 2012.

TIBOLA, C. S.; FERNANDES, J. M. C.; DEL PONTE, E. M.; MALLMANN, C. A.; DILKIN, P.; LIMA, M. I. P. M.; PAVAN, W. Indicações técnicas para minimizar a contaminação de Wheat por micotoxinas. Passo Fundo: Embrapa Wheat, 2013. 39 p. (Boletim de Pesquisa e Desenvolvimento, 11).

TROMBETE, F. M.; MORAES, D. A.; PORTO, Y. D.; SANTOS, T. B.; DIREITO, G. M.; FRAGA, M. E.; SALDANHA, T. Determination of aflatoxins in wheat and wheat by-products intended for human consumtion, marketed in Rio de Janeiro, Brazil. Journal of Food and Nutrition Research, Rio de Janeiro, v. 2, n. 10, p. 671674, 2014.

TWARUZEK, M.; BŁAJET-KOSICKA, A.; WENDAPIESIK, A.; PAŁUBICKI, J.; GRAJEWSKI, J. Statistical comparison of Fusarium mycotoxins content in oat grain and related products from two agricultural systems. Food Control, Vurrey, n. 34, p. 291-295, 2013. 
